\title{
"The role of Corporate Social Responsibility in the decision-making process of consumers in Ukraine"
}

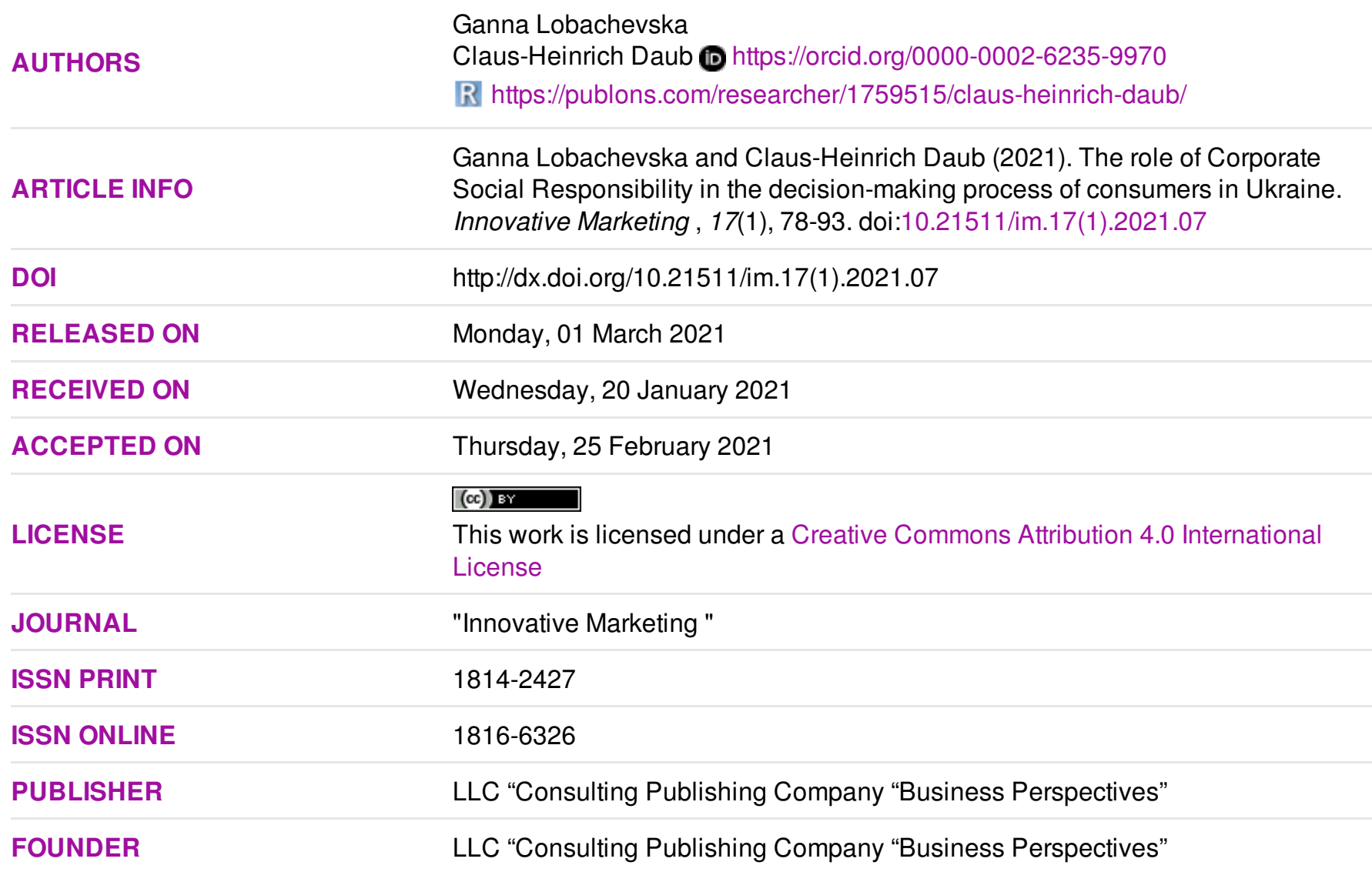

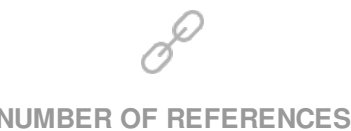

84

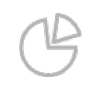

NUMBER OF FIGURES

2

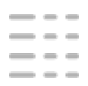

NUMBER OF TABLES

3

(C) The author(s) 2021. This publication is an open access article. 


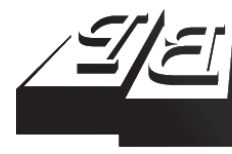

\section{BUSINESS PERSPECTIVES}

LLC "CPC "Business Perspectives" Hryhorii Skovoroda lane, 10, Sumy, 40022, Ukraine www.businessperspectives.org
Received on: $20^{\text {th }}$ of January, 2021 Accepted on: $25^{\text {th }}$ of February, 2021 Published on: $1^{\text {st }}$ of March, 2021

(C) Ganna Lobachevska, Claus-Heinrich Daub, 2021

Ganna Lobachevska, Master of Science, School of Business, University of Applied Sciences and Arts Northwestern Switzerland, Olten, Switzerland. (Corresponding author)

Claus-Heinrich Daub, Dr., Professor, Institute of Management, University of Applied Sciences and Arts Northwestern Switzerland, Windisch, Switzerland.

\title{
THE ROLE OF CORPORATE SOCIAL RESPONSIBILITY IN THE DECISION-MAKING PROCESS OF CONSUMERS IN UKRAINE
}

\begin{abstract}
This paper aims to investigate the impact of Corporate Social Responsibility (CSR) of Fast Moving Consumer Goods (FMCG) companies on consumer buying behavior in the Ukrainian market. The qualitative data for this study were collected with the help of semi-structured interviews conducted with a total of 10 respondents, including 5 Ukrainian consumers (with different levels of responsible consumption adoption) and 5 CSR experts from FMCG companies located in Ukraine (both local and global; with CSR adoption level varying from low to well-developed).
\end{abstract}

The data obtained for this study revealed that the level of consumer awareness about CSR in Ukraine is still low. However, the level of awareness and the actual consumption of responsible products are constantly growing. The results also show that Ukrainian consumers who already have some level of awareness about CSR perceive CSR communication as more credible when it does not originate from the company directly or is endorsed by a third party. At the same time, interviewed experts stated that to raise awareness among the wider population, FMCG companies have to communicate their CSR achievements directly and massively. Ukrainian consumers are mostly impacted by the product-related CSR type, such as bio-ingredients and sustainable packaging. Price premium for responsible products is the key factor that causes the "intentionbehavior gap" in Ukraine.

Practitioners from the FMCG industry in Ukraine may use the information provided by this study to shape their CSR strategies, which will allow them to cater to societal demands and, as a result, impact consumer buying behavior.

\section{Keywords}

JEL Classification

\section{INTRODUCTION}

Nowadays, the fast-growing population and a considerable increase in consumption lead to ubiquitous pollution of air, water, and land and putting an ever-growing pressure on the scarce resources and the entire ecosystem. Planetary boundaries have definitely been exceeded what results in significant consequences for the whole society (Rockström et al., 2009). More and more companies and consumers are questioning the traditional way of running a business in this context.

The idea that business has responsibilities beyond profit and should add social and environmental value (Crane et al., 2019) was widely accepted and integrated into the strategies of a vast variety of companies worldwide, especially during the last two decades. According to a survey conducted by Accenture in 2019, 99\% of CEOs believed that 
"sustainability issues will be critical to the future success of their business" (Accenture Strategy, 2019, p. 23). Moreover, in 2019, the CEOs of more than 180 US companies have signed the "statement of corporate purpose" with the key message that the companies' social responsibilities are more important than profit (Dilts, 2019).

At the same time, sustainable and ethical consumption is gaining momentum at a high pace as well, partly triggered by sustainable marketing and CSR communication, partly because customers are getting aware of today's global challenges and, as a result, become more conscious during the purchase process (Ethical Consumer, 2019; Jackson, 2006). This, in turn, provokes businesses to move further in integrating CSR practices. In this context, the literature repeatedly refers to companies and consumers' "shared responsibility" (Brinkmann \& Peattie, 2008).

However, while the market of ethical products is growing faster than the conventional one (KronthalSacco \& Whelan, 2019) and there is a clear shift towards business "greening" (Worthington, 2013), the overall consumption and production patterns are still far from sustainable. Most of the companies are going "green" for very practical business-driven reasons and perceive CSR as a means to improve financial performance, cut costs, enhance brand reputation, etc. (ING, 2018). Thus, though in a long-term perspective, strict adherence to the "triple bottom line" principle (Elkington, 1997) is not a question of corporate financial performance improvement but, rather, a company's survival, in a short-term, some kind of business case for CSR should be developed in order to attract attention and gain support from the business sector (Kurucz et al., 2008).

The consumer's perception of the company's CSR activities is an important component of a business case for CSR, as the implementation of social responsibilities that are aligned with customers' expectations, may result in enhanced corporate reputation, brand equity, consumers' loyalty and ultimately influence the consumer buying behavior (Torres et al., 2012).

Though previous studies already tried to explain the influence of CSR on consumer buying behavior, they were mostly conducted in economically developed Western countries (Oberseder et al., 2011). Meanwhile, this topic is completely under-researched in Eastern Europe in general and in Ukraine in particular. Simultaneously, the societal demand for corporate responsibility in ex-soviet countries is currently rising, especially during the last decade. This creates a significant research gap, which this study aims partly to fill.

To shed the light on the criteria that may increase the probability of considering CSR by the consumers in their purchase decision-making process, the study intended to answer how the FMCG industry in Ukraine can shape the CSR strategies to tackle new societal demands and influence consumer buying behavior.

\section{LITERATURE REVIEW}

\subsection{Corporate social responsibility and the reasons behind "greening" the business}

Corporate Social Responsibility (CSR) is a complex concept and, in general, implies that except making a profit, business is supposed to add social and environmental value (Elkington, 1997) to a wider audience of stakeholders (Freeman, 1984) that usually encompasses employees, customers, suppliers, local communities (Panapanaan et al., 2003), shareholders, environment, etc. (Spiller, 2000).

While the classical four-part CSR model developed by Carroll (1991) defines CSR as a hierarchical order of economic, legal, ethical, and philanthropic responsibilities (where the two former are supposed to be fulfilled by the company in the first place, and the two latter are accordingly described as expected and desired), more recent academic lit- 
erature, as well as business world executives, challenge this pragmatic view of CSR, outlining that such approach does not provide the solution to a situation in which "two or more responsibilities are in conflict" (Crane et al., 2019, p. 52) and emphasize the necessity of shift from a pyramid concept of CSR, where economic goals build the basis and are considered supreme, to a balanced model, where all three dimensions of corporate responsibility - economical, environmental, and social - are equally important and must be integrated into management processes (Hahn \& Figge, 2011; Gladwin et al., 1995). However, in reality, the business remains primarily money-driven (Kotler \& Lee, 2005), and the recent sustainability study demonstrates that the key motive for "greening the business" is still revenue growth (ING, 2018). In this regard, the business case for CSR remains an important topic both for academia and the business environment.

During the last two decades, an extended body of academic literature and empirical studies aimed to find out whether there is a "business case for CSR" or, in other words, to define if it is economically efficient to invest in CSR (Carroll \& Shabana, 2010; Daszynska-Zygadlo et al., 2016; Hoepner \& Yu, 2010). When dissecting the business case for CSR, the scholars distinguish between different sources of CSR economic impact, namely cost and risk reduction, profit maximization and competitive advantage, reputation, legitimacy, and synergistic value creation (Kurucz et al., 2008), increased staff motivation, enhance capacity to innovate, brand value, reputation, and development of closer links with customers (Jones, Comfort, Hillier, \& Eastwood, 2005). However, one of the most important questions within the 'business case for CSR' context is whether and how the company's responsibility affects consumer buying behavior and results in increased sales and market share (Kotler \& Lee, 2005).

\subsection{CSR's impact on consumer attitude and behavior}

When considering the CSR influence on consumers, it is crucial to distinguish between the impact of the former on consumer attitude and consumer behavior as the attitude toward the object or phenomenon (in this case - to the company, its brands, or products) does not necessarily predict the behavior related to this object or phenomenon (the purchase of particular products or services) (Glanz et al., 2015).

In recent years, the relationship between CSR and attitude towards the company and its brands was widely studied and, in most cases, has been characterized as positive in different industries and various cultural contexts (Esmaeilpour \& Barjoei, 2016; Hsu, 2012; C. Lee, Chang, \& H. Lee, 2017; Raza Naqvi, 2013; Staudt, Shao, Dubinsky, \& Wilson, 2014; Torres et al., 2012; Wang et al., 2015).

However, the empirical findings regarding the CSR impact on consumer buying behavior are less unequivocal (Oberseder et al., 2013; Sen \& Bhattacharya, 2001). Some scholars found out that CSR has a direct positive impact on consumer behavior in different geographical settings (Huang et al., 2014; Kannaiah \& Jayakumar, 2018; SchrammKlein et al., 2016; Wang \& Juslin, 2009), stating that "all of the CSR components have a significant association with consumers' buying behavior" (Farrukh, 2016, p. 249).

At the same time, other studies led to mixed or opposite results, highlighting that CSR itself does not have a significant impact on the buying decision-making process both because most consumers are still not aware of what CSR entails (Arli \& Lasmono, 2010; Fernández \& Rajagopal, 2013) and "because traditional purchasing criteria continue to prevail, in particular the price" (Boccia, Rosa, \& Covino, 2019, p. 97). Moreover, the impact of CSR on consumers is also moderated by numerous factors, such as demographic and personal characteristics of customers, product and industry (Tian, Wang, \& Yang, 2011; Vázquez-Burguete, Sahelices-Pinto, \& Lanero-Carriz, 2017), as well as quality, brand, service (Oberseder et al., 2011) and country of origin (Ferreira \& Ribeiro, 2017). The present study aims to identify the decisive factors that influence CSR integration into consumer buying behavior and to analyze how and why they influence consumer behavior in Ukraine.

\subsection{Conceptual framework development}

Before purchasing and adopting the product, a consumer goes through various stages of the decision-making process and can terminate the 
process at any of the stages (Hassinger, 1959; Thøgersen \& Zhou, 2012). To explain how CSR may influence consumers, the Theory of Reasoned Action (TRA) was considered the most appropriate one as it clearly reflects the process of the ethical decision-making process (Fishbein \& Ajzen, 1975). Moreover, the Social Cognitive Theory (SCT) (Bandura, 1986) was also involved in the conceptual framework creation as it allows expanding the interconnections of the TRA.

\subsubsection{Cognitive decision-making models}

The TRA is based on the assumption that the individual's behavior may be predicted by behavioral intention (Glanz et al., 2015). In turn, behavioral intention is determined by the person's attitudes and subjective norms (Fishbein \& Ajzen, 1975).

The application of TRA in the context of ethical consumption was criticized as this model views the purchase decision-making process as a part of the rational thought process, while the consumers' behavior is not always rational (Crane et al., 2019). Even consumers who have a positive attitude and intention towards purchasing ethical products do not always translate this attitude into the actual purchase (Boccia et al., 2019; De Pelsmaker et al., 2005). This paradox between ever-growing societal demand for CSR engagement and limited involvement of consumers in ethical and sustainable consumption (Oberseder et al., 2011) may be explained by a socalled "attitude-behavior gap" (Auger \& Devinney, 2007). The key reasons behind the "attitude-behavior gap" will be discussed later in this paper.
According to the SCT (Bandura, 1986), there is a triadic reciprocal interaction between the individual's behavior, personal, and environmental factors. Bandura (1986) states that the individual's behavior is impacted by an individual's personal and cognitive factors and the environment in which the individual lives (e.g., the opinions of referent individuals, social pressure). This behavior, in turn, affects the individual and the environment. At the same time, individuals can choose the environment and people they communicate with, and in turn, this environment influences their concerns and beliefs.

The TRA and SCT aim to determine the factors that affect the individual's behavior and explain how these factors interact. However, these two theories have some differences in approaches and definitions of similar stages. For the sake of this study, the commonplaces of these two models were determined and merged, while some of the attributes were renamed to reflect ethical consumer behavior better. In this regard, "Personal factors" were titled "Personal concerns regarding CSR" while "Environment" and "Subjective norms" were merged and renamed to "Societal approval of responsible consumption", as reflected in Figure 1.

\subsubsection{Key factors impacting CSR integration into the consumer decision-making process}

Based on the comprehensive literature review, it was revealed that the key factors that hinder or enhance the CSR impact on consumer buying deci-

Source: Based on Bandura (1986), Fishbein and Ajzen (1975).

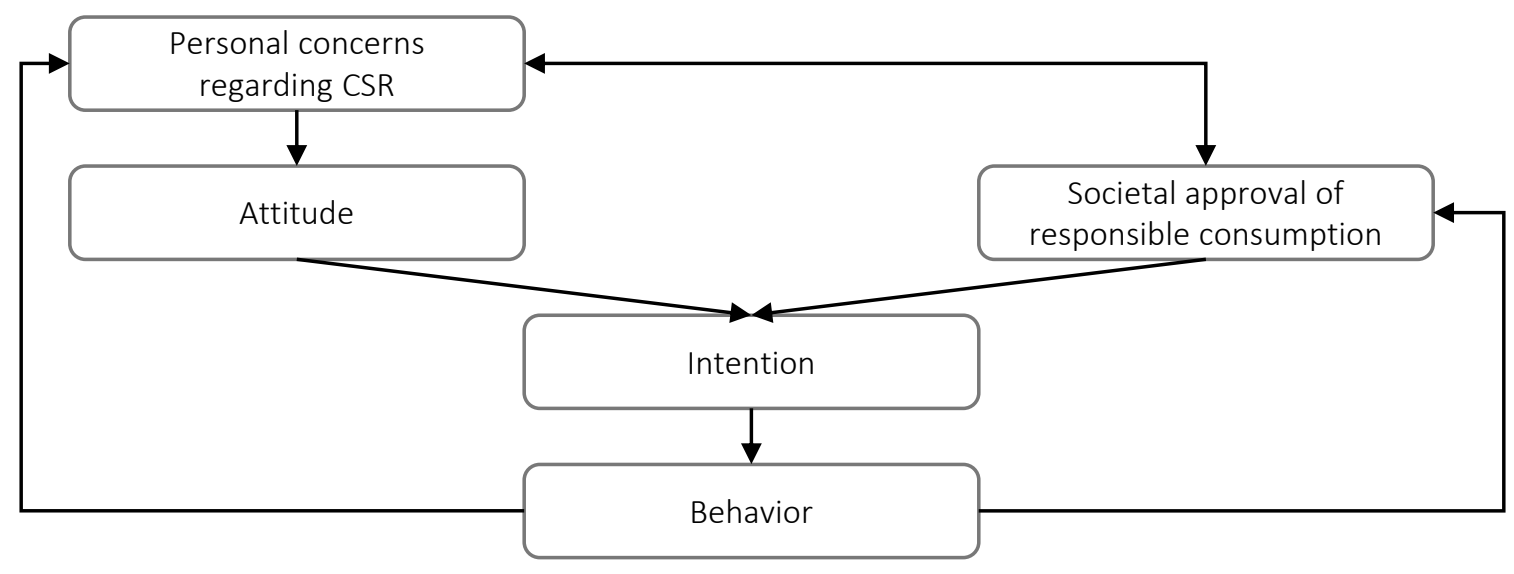

Figure 1. Adapted model of the decision-making process based on the merge of TRA and SCT 
sion-making process are the level of awareness about CSR, how CSR is communicated to the customers, the type of CSR initiatives and the price difference between ethical and conventional products (Arli \& Lasmono, 2010; Bhattacharya \& Sen, 2004; Boccia et al., 2019; Boulstridge \& Carrigan, 2000; Du et al., 2010; Fernández \& Rajagopal, 2013; Karaosman et al., 2015; Oberseder et al., 2011; Oberseder et al., 2013; Park et al., 2014; Peloza \& Shang, 2011; Schmeltz, 2012; Sen et al., 2006). The combination of these factors determines whether consumers will opt to buy responsible products or not.

The CSR-related factors mentioned above affect consumers at different stages of the purchase decision-making process. Mapping these factors to particular stages of the model received in Figure 1 resulted in a comprehensive conceptual framework used as the base of the current study (Figure 2).
Awareness about CSR is a prerequisite for "considering CSR in the purchase process" (Oberseder et al., 2011, pp. 453-454). The level of consumers' awareness about the organization's CSR record is positively related to consumers' attitudes (Pomering \& Dolnicar, 2009), as depicted in Figure 2. However, awareness itself cannot positively influence the consumer's attitude toward buying the product as the skepticism about CSR information is considered high (Du et al., 2010). Hence, awareness can contribute to a favorable consumer attitude only if coupled with trust in certain CSR activities. Besides, attitude closely depends on personal concerns, interconnected with societal approval.

Effective CSR communication may increase awareness, foster trust and enhance consumer attitude (Karaosman et al., 2015). Yet, to develop effective CSR communication, practitioners must know what

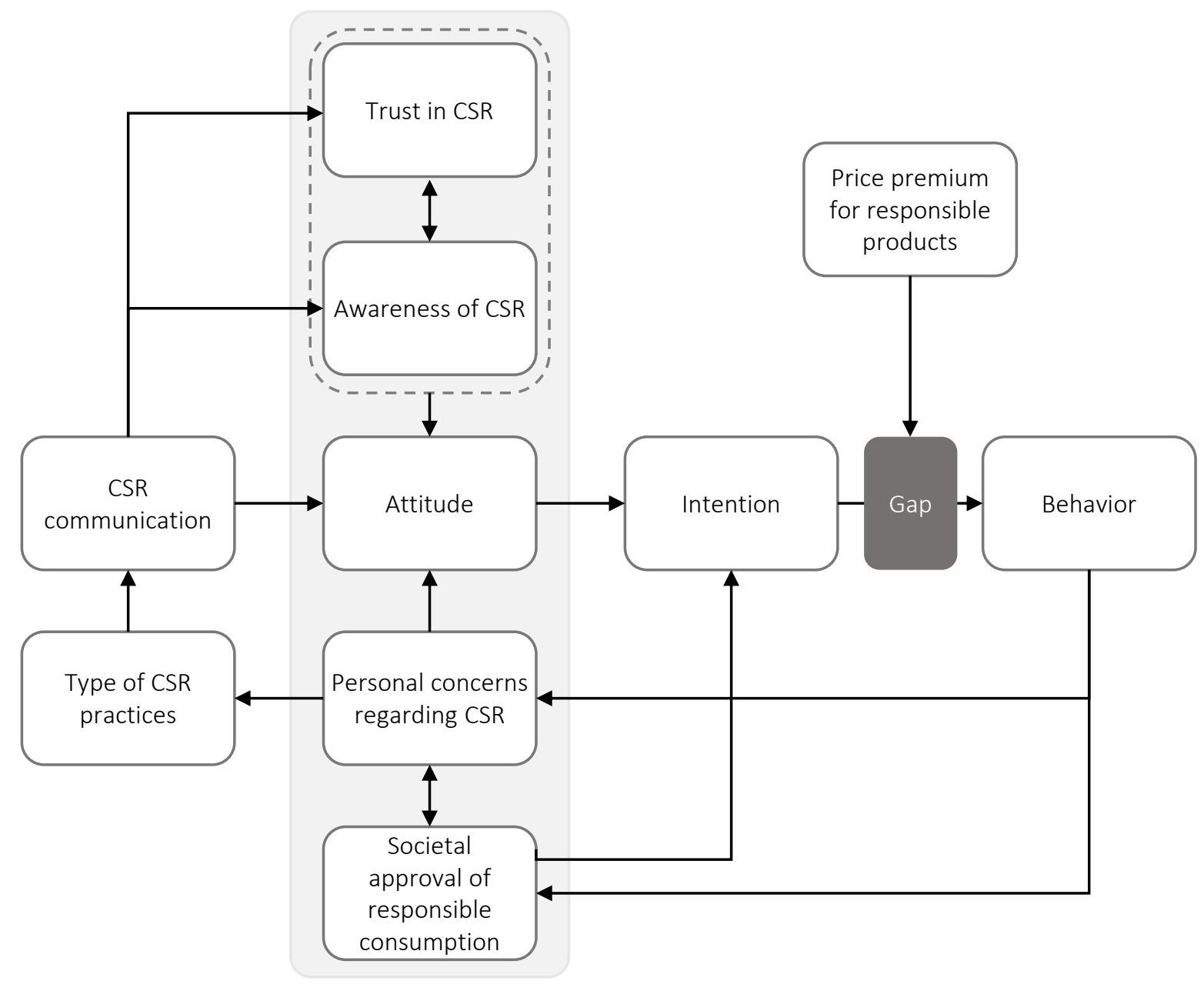

Figure 2. Conceptual research framework 
has to be communicated and how it has to be communicated (Kim \& Ferguson, 2014). Simply put, the answer to the question "how to communicate" helps enhance trust and reduce consumer's skepticism or, in other words, it makes communication credible. On the other hand, the question "what communicate" helps the company align its CSR message with consumers' concerns and values and make communication personally relevant for them. The Elaboration Likelihood Model (Petty \& Cacioppo, 1986) illustrates that credibility of communication and its relevance are crucial factors that affect the communication impact and that individuals can process the message and change the attitude only if both criteria are met.

While previously discussed aspects mostly affect customers' attitude to the company and, as a result, intention to consume sustainable products, the last but not least criterion - price - fills out (or broadens) the "attitude-behavior gap" discussed above (Karaosman et al., 2015), as illustrated in Figure 2.

\section{HYPOTHESES DEVELOPMENT}

As mentioned earlier, this paper aims to explain how the FMCG industry in Ukraine can shape the CSR strategies to tackle new societal demands and influence consumer buying behavior. To further specify the focus of the research, four research sub-questions (RSQ) were determined:

RSQ1: What is the overall level of awareness about CSR activities among consumers in Ukraine?

RSQ2: What are the most credible CSR communication practices in Ukraine? How can companies make sure that consumers perceive CSR communication positively?

RSQ3: Which CSR types have the greatest relative importance to the consumers in Ukraine?

RSQ4: What hinders Ukrainian consumers from purchasing responsible FMCG products?

Consumers' low awareness remains the key obstacle "in companies' attempts to maximize business benefits from their CSR activities" (Du et al., 2010). No study was conducted so far in order to measure the level of CSR awareness among Ukrainian consumers. Simultaneously, according to the latest Sustainable Development Report (Sachs et al., 2019), Ukraine is still far from reaching Sustainable Development Goal 12, namely 'Responsible Consumption and Production' (Sachs et al., 2020). The assumption that responsible consumption is an indirect indicator of the population's awareness about CSR led the researchers to assume that the level of awareness about CSR in Ukraine is rather low. Moreover, the CSR tradition appeared and developed in Eastern Europe, in general, and in Ukraine, in particular, much later than in Western Europe (Steurer \& Konrad, 2009). The concept of CSR in its classical meaning was unknown in the former Soviet Union (Filosof et al., 2012), and after the collapse of the USSR, the ex-soviet republics were more focused on ensuring economic and political stability than on CSR issues. Even though starting in the 2000s, particular businesses started to implement CSR practices in Ukraine (Kurinko, 2016), it was argued that in 2005 the CSR concept as it is perceived in the West "is yet to be introduced in Ukraine" (Vorobey, 2005 , p. 219). The working group aimed to develop a National CSR strategy in Ukraine was created only in 2013 (The Verkhovna Rada of Ukraine, 2013). Alas, this group could not finish the strategy development as in 2013-2014, Ukraine had to cope with serious external and internal difficulties. Thus, the work of the National CSR strategy development group was continued only at the beginning of 2016 (Kurinko, 2016). All the mentioned factors bring us to the following working proposition (WP):

WP1: The level of awareness is still low in Ukraine, which is one of the key reasons for low attitude and intention to purchase responsible products.

Besides the measurement of the level of awareness about CSR among Ukrainian consumers, another goal of the paper is to answer one of the key questions related to the effectiveness of CSR communication: how the information about CSR has to be delivered to Ukrainian consumers to be perceived as credible, to enhance trust, and to reduce stakeholder skepticism (Du et al., 2010). The majority of studies that investigated the credibility of CSR 
communication agree on the fact that information about CSR activities and achievements is better accepted when third parties endorse it and when it is communicated through sources not controlled by the company directly (Du et al., 2010; Kim \& Ferguson, 2018; Schmeltz, 2012).

WP2: CSR communication is more credible for Ukrainian consumers when it is not originated from the company directly or endorsed by third parties.

Besides being credible, CSR communication also has to be relevant to consumers. To stimulate favorable consumers' behavioral attitude and purchase intention, the company has to focus its CSR communication on the matters (or CSR types) aligned with consumers' concerns (Kim \& Ferguson, 2018; Oberseder et al., 2011). According to Peloza and Shang (2011), CSR may create value for consumers in different ways. They proposed that the CSR in philanthropy and business practices enhance other-oriented value, while the product-related CSR enhances both other- and self-oriented value. It is generally argued that consumers tend to focus on and prioritize self-centered activities or product-related CSR (Peloza \& Shang, 2011; Schmeltz, 2012).

WP3: Product-related CSR type has the biggest influence on Ukrainian consumers' attitude and intention to purchase the products.

Considering the facts that price and financial situation of consumers are still the crucial factors that impact consumer buying behavior significantly (Arli \& Lasmono, 2010; Boccia et al., 2019) and that ethical and "green" products are usually more expensive than conventional ones, it is logical that the price premium for responsible products is one of the key reasons of a so-called "intention-behavior gap" both in developing and developed countries (Carrington et al., 2010; Karaosman et al., 2015; Oberseder et al., 2011). Consequently, it is plausible that this statement would be relevant in Ukrainian contexts as well, especially considering the facts that in the context of economic crisis, consumers tend to be very cautious and cut spending where possible (Conroy et al., 2015), and Ukraine experienced an economic downturn during the last six years that contributed to increasing consumers' anxiety. Now, Ukraine is ranked $111^{\text {th }}$ in the World Bank's list of countries according to their GDP (PPP) per capita (The World Bank, 2018). Considering the mentioned factors, the following working proposition was formulated:

WP4: In Ukraine, the price premium is the key reason for the "intention-behavior gap" in the context of the decision-making process related to ethical consumption.

\section{METHODS}

\subsection{Research approach and design}

A deductive approach was applied for this study, implying that a theory-based conceptual framework and working proposition were guiding both data collection and analysis. Considering the complexity of the research question and the fact that the current research goal is to explain values and perceptions standing behind consumer behavior, a qualitative single-case study method was chosen for the present paper (McCracken, 1988; Saunders et al., 2007). Furthermore, through the mean of qualitative method, the researchers expect to explore and reveal new findings as to the field of CSR, in general, and the impact of CSR on consumer behavior, in particular, is underexplored in Ukraine. At the same time, it must be kept in mind that as this study adopted a qualitative approach, it has certain limitations inherent in this research design. First and foremost, it is not possible to widely generalize the results of such studies (Oberseder et al., 2011). To ensure the consistency of the case study design, the researchers were guided by the four quality criteria discussed further (Yin, 2014).

\subsection{Sampling strategy, data collection, and quality criteria}

The empirical data for this study were collected with the help of semi-structured interviews designed based on developed working propositions while simultaneously keeping the overarching research question in mind. To eliminate the risk of researchers' "subjective judgments" that may distort the qualitative study during data collection and to test the research design for construct va- 
lidity, the mean of data triangulation was applied (Carter et al., 2014; Yin, 2014). In this regard, the researchers interviewed Ukrainian consumers and CSR experts from FMCG companies based in Ukraine to gain different perspectives on the research topic and make sure that the results will reflect genuine tendencies and trends (Carter et al., 2014). Moreover, to further ensure the accuracy of the research, the preliminary case study results were reviewed by several consumers and expert participants.

The participants were included in this study based on the purposeful sampling approach (Palinkas et al., 2015) in strict accordance with the basic sets of criteria developed for both groups before data collection. The expert sample included representatives of both global and local FMCG players, and the consumer sample was aimed to include participants with diverse demographic characteristics and a certain level of awareness about responsible consumption. A total of 10 face-to-face interviews were conducted in 2020 (5 with experts and 5 with consumers - the overview of interview partners is presented in Appendices A and B) based on the guidelines developed as a part of the case study protocol in order to keep the interviews focused on the key matters, to standardize the process, and to mitigate potential issues during the data collection. The case study protocol that was developed before collecting the case study evidence also ensures the reliability of the research (Yin, 2014).

"Relying on theoretical proposition" (Yin, 2014, p. 136) was the key strategy for the data analysis. This implies that collected data were analyzed within a clear causal frame created by a conceptual framework based on an extensive reviewed literature body (Figure 2). Thus, theoretical triangulation addresses the internal validity quality criterion. Pattern matching technic applied during the data analysis fulfills the criterion of internal validity as well (Miles et al., 2014). The assessment of findings versus chosen theoretical frame and developed working propositions also helped the researchers ensure external validity and generalize the findings of case study research beyond the present study (Yin, 2014). The data obtained during the interviews was coded in CAQDAS Atlas.ti software (Saldana, 2015).

\section{DATA ANALYSIS AND RESULTS}

This section presents the results of analysis of data obtained from the interviews and discusses whether these results support the working propositions derived from the literature.

\subsection{Awareness of CSR}

As mentioned earlier, the consumers chosen for this study already possess some level of knowledge about CSR and sustainable consumption. For this reason, to evaluate the overall level of CSR awareness in Ukraine, only the experts' answers on this matter were analyzed.

Table 1. Examples of expert statements regarding the CSR awareness level in Ukraine

\begin{tabular}{|c|c|c|}
\hline & \multicolumn{2}{|c|}{ CSR awareness } \\
\hline & Factual level & Trend \\
\hline Expert 1 & $\begin{array}{l}\text { "I would describe the } \\
\text { level of awareness [...] } \\
\text { as very low. I suppose } \\
\text { that about } 2 \% \text { of the } \\
\text { population, in general, } \\
\text { have at least some idea of } \\
\text { ethical consumption and } \\
\text { production". }\end{array}$ & $\begin{array}{l}\text { "I think the trend is } \\
\text { growing, but very slow". }\end{array}$ \\
\hline Expert 3 & $\begin{array}{l}\text { "The percentage of } \\
\text { theople who think about } \\
\text { companies, about } \\
\text { sustainable consumption } \\
\text { is small". }\end{array}$ & $\begin{array}{l}\text { "According to researches } \\
{[\ldots], \text { people are really }} \\
\text { looking at the social } \\
\text { responsibility of } \\
\text { companies". }\end{array}$ \\
\hline Expert 4 & $\begin{array}{l}\text { "I would say that about } 1 \% \\
\text { (maybe } 1.5 \% \text { or maximum } \\
\text { 2\%) of all our customers } \\
{[\ldots] \text { know something }} \\
\text { about responsibility or are } \\
\text { actively involved". }\end{array}$ & $\begin{array}{l}\text { "I see that people's } \\
\text { awareness is growing. } \\
{[\ldots .] \text { all consumers }[. . .]} \\
\text { understand the current } \\
\text { global challenges and } \\
\text { understand it very } \\
\text { quickly [...]". }\end{array}$ \\
\hline
\end{tabular}

All the interviewed experts evaluated the level of awareness in the country as extremely low. Though no earlier study that would measure the level of awareness about CSR in Ukraine was conducted, some of the experts stated that in their opinion, not more than $2 \%$ of the Ukrainian population has at least basic information about CSR in general and the efforts of certain companies in particular, while even fewer people base their purchase decisions on this kind of information (Table 1).

According to the experts, the insufficient level of awareness is caused by the absence of CSR com- 
munication or the irrelevance of existing communication to consumers. Moreover, the economic instability and, as a result, a low level of income make people focused on the fulfillment of their basic needs; hence, ethical consumption is not one of their key concerns. Simultaneously, the level of awareness in Ukraine is growing and gradually changes consumers' mindset. Most of the participants strongly related the insufficient level of CSR awareness and low purchase behavior of responsible FMCG products.

\subsection{CSR communication}

The obtained data revealed that experts and consumers interviewed in Ukraine do not have the same CSR communication perspective. The vast majority of experts were convinced that only massive and direct TV and digital communication about CSR and responsible consumption could raise an extremely low level of consumers' awareness. According to the experts, most consumers in Ukraine do not know what greenwashing is and accept the information from the company-controlled sources as trustworthy. On the contrary, the analysis of consumers' answers showed that the coverage does not have to be the only focus of CSR communication strategy in the country trust in CSR also plays a crucial role in the effectiveness of communication about ethics. Even though the majority of the interviewed consumers do trust in CSR information originated from company-controlled sources, this trust is possible only under certain circumstances in all cases. For instance, some consumers mentioned that they do not trust in CSR communication originated from Ukrainian FMCG companies and in the local eco-labels placed on such products due to the absence of the legal base that would regulate and control the production of responsible products and placement of such labels in Ukraine (Consumers $2,4)$. In this regard, consumers admitted that to believe in CSR communication from the company directly, they either need to trust this company in general based on previous experience or to see a lot of evidence and confirmations of particular CSR activity in communication. Some consumers are especially trustful to the information about CSR when it comes from the people they know, from the bloggers they follow on social media and NGOs.

\subsection{CSR type}

Regarding personal concerns, Ukrainian consumers demonstrated a clear inclination towards environmental CSR. In particular, the majority of interviewed consumers were strongly concerned with the issue of recycling. This is probably caused by the fact that $94,6 \%$ of the waste in Ukraine is still sent to landfills: only $3 \%$ of solid waste in Ukraine is recycled, and $2,4 \%$ is incinerated (Kuryshko, 2018). Moreover, the government almost not addressed this problem (Cherinko \& Balanyuk, 2018; Karhova, 2018). Simultaneously, the experts have highlighted that due to the absence of proper infrastructure for recycling in Ukraine, only the most conscious consumers are ready to sort the garbage; hence, not many consumers are paying attention to it when buying FMCG products. Yet, when no extra efforts are required from consumers, they perceive the responsible packaging initiatives very positively (Expert 3).

However, even if for all the interviewed consumers, sustainable packaging is very important when purchasing FMCG products; it is usually not the first criterion. The most important factor that positively impacts consumers' concerns, attitude, and, as a result, purchase intention is ingredients. Bio or natural ingredients were mentioned considerably more often than other CSR types as the key factor consumers pay attention to when buying FMCG products. All the consumers were unanimous about this and strongly supported by the experts as well:

"It's absolutely certain that the consumer is most interested in and motivated to buy the "green" features that are integrated into the product. Now there is a great demand for everything "natural", emphasis on the ingredients" (Expert 1).

"For people, what is inside matters most: it's the quality of the product and its ingredients. It affects the purchase decision most" (Expert 4).

Consumers prefer biological ingredients because such products are both safe for them personally and for the environment (Consumer 5), as well as because the information about ingredients is easily accessible on the packaging; hence, they do not need to spend time on finding it: "I pay attention 
first of all on the ingredients of the product, as it is the easiest criterion to know - you can just read it on the package. Simply because this information is on the surface, I don't need to look for it on purpose" (Consumer 2). Some consumers also mentioned that other CSR aspects and types, such as environmentally friendly business practices, are also important for them and would have an impact on their buying behavior if they would know about them, or in other words, if such information would be explicitly communicated (Consumer 2).

According to Ukrainian experts, to make an impact on consumer buying behavior, "CSR initiatives must be absolutely local" (Expert 1). All the interviewed consumers, indeed, confirmed that they would prefer the products of the companies that implement their CSR strategies and activities within Ukraine.

\subsection{Intention-behavior gap}

Most interviewed consumers mentioned that they are ready to pay more for responsible products, especially if the price difference is not significant. At the same time, most of the consumers interviewed in Ukraine have higher than average income; hence, their answers to this question cannot be generalized to the whole Ukrainian population.

As for the experts' point of view, all of them repeatedly mentioned that the price premium is a huge barrier that hinders the wider public from purchasing FMCG products of responsible companies (Expert 3, Expert 4). Simultaneously, it was emphasized that when the consumers have a really deep understanding of why it is important and better to buy responsible products, the obstacle of the price premium is partly eliminated (Expert 4).

Among other barriers between the desire to buy responsible products and the actual purchase, Ukrainian consumers also mentioned accessibility, level of performance, the comfort of "green" products, and the issue that many products are only partly "green" (e.g., when the ingredients are sustainably sourced, but the packaging is not sustainable) (Consumer 1, Consumer 5).

Both consumers and experts admitted that the level of ethical consumption is growing (though not very fast and not at the same pace in the big cities and in rural areas), and they are convinced that it will develop even more in the future. However, in light of the COVID-19 outbreak, Ukrainian experts were rather pessimistic regarding the future scenarios. The COVID-19 lockdown may have a deeply devastating aftermath for the country going through the economic crises even before the pandemic. In this case, they expect that consumer concerns about CSR and sustainable consumption will eliminate dramatically as consumers will become even more price-sensitive (Expert 4).

\section{DISCUSSION AND HYPOTHESES TESTING}

In the current section, the researchers discuss whether the results of the analysis of collected data support the research hypotheses.

The first hypothesis was well-supported during the data analysis. This means that the data collected for this study evidenced that the level of awareness of CSR is still very low in the Ukrainian context, and this is the key reason why consumers do not consider CSR the purchase criterion when choosing FMCG products (Karaosman et al., 2015; Oberseder et al., 2011; Sen et al., 2006). Simultaneously, the level of awareness in Ukraine is gradually growing, there is a significant trend aimed at sustainability, and this trend is gradually changing the mindset of particular consumers and the whole society forming new patterns and consumer habits.

The collected data only partly supported the second hypothesis. It turned out that even though interviewed Ukrainian consumers are looking for some kind of confirmation and endorsement of CSR information (Du et al., 2010; Kim \& Ferguson, 2018), the wider pool of consumers in Ukraine apparently trust the CSR information communicated directly by the company more often.

Hypothesis 3 was strongly supported by data analysis. Collected data provided sufficient evidence that Ukrainian consumers' buying behavior is primarily affected by product-related CSR type (most notably, ingredients but also the sustainability of the packaging), which supports the conclusions of Peloza and Shang (2011). 
Interestingly, Ukrainian consumers prefer the CSR activities conducted in their own country to the point that geographical context may impact their buying behavior, which corresponds to the findings of Torres et al. (2012) and Karaosman et al. (2015).

Hypothesis 4 was also well supported by the findings of this study. The higher price of responsible products is meant to be the key obstacle between consumers' intention to purchase responsible companies' products and the actual purchase (Carrington et al., 2010; Karaosman et al., 2015).
The importance of this barrier may be increased even further by the COVID-19 outbreak. The economic downturn caused by the COVID-19 lockdown will most likely have the strongest negative effect on developing countries and lower-income class consumers (Advantix Digital, 2020; Conroy et al., 2015). Consequently, this may indeed result in the situation when consumers affected by the economic crisis will be induced to switch to more affordable products. However, it is hard to predict how the COVID-19 pandemic will influence responsible products' consumption as the whole picture of the COVID-19 aftermath is still not clear.

\section{CONCLUSION}

This study revealed that the impact of CSR on consumer buying behavior is still modest in Ukraine. The key reason for the limited role of CSR in the consumers' decision-making process is the low level of awareness about CSR. Thus, the companies have to focus on raising consumers' awareness first.

Product-related CSR activities have the biggest influence on consumers' buying behavior in Ukraine. Hence, the FMCG companies have to pay particular attention to adapting their products' ingredients and the development of sustainable packaging. Moreover, managers have to think about supporting their communication about sustainable ingredients and packaging with trustworthy labels. Simultaneously, the interviewed experts emphasized that due to the low level of CSR awareness, it is better to concentrate on CSR communication coverage than credibility. In this case, practitioners may try to find a compromise between these two CSR communication-related goals. Besides, a place has to be concerned when developing, implementing, and communicating CSR activities as the collected data demonstrated that Ukrainian consumers strongly prefer when responsible actions of FMCG companies take place in their own country.

In Ukraine, the price premium is the key reason that explains the discrepancy between consumers' intentions and actual behavior in the context of responsible consumption. Consequently, it has to be figured out what range of price premium consumers can pay for responsible products and manage the pricing accordingly where applicable. In general, the growth of responsible product consumption in Ukraine evidence that the societal demand for CSR is gradually increasing in the country, meaning that FMCG companies have to shape (or in some cases start to develop) their CSR strategies and communication accordingly. In this way, they can increase their chances of winning consumers' loyalty and trust.

\section{AUTHOR CONTRIBUTIONS}

Conceptualization: Claus-Heinrich Daub, Ganna Lobachevska.

Data curation: Ganna Lobachevska.

Formal analysis: Ganna Lobachevska.

Investigation: Ganna Lobachevska.

Methodology: Claus-Heinrich Daub, Ganna Lobachevska.

Supervision: Claus-Heinrich Daub.

Validation: Claus-Heinrich Daub.

Visualization: Ganna Lobachevska.

Writing - original draft: Ganna Lobachevska.

Writing - review \& editing: Claus-Heinrich Daub, Ganna Lobachevska. 


\section{REFERENCES}

1. Accenture Strategy. (2019). The

Decade to Deliver. A call to

business action. The United

Nations Global Compact -

Accenture Strategy CEO Study on Sustainability 2019.

2. Advantix Digital. (2020). Marketing Trends and effects from $\mathrm{CO}-$

VID-19 (Coronavirus). Retrieved from https://advantixdigital.com/ blog/marketing-trends-and-effects-from-covid-19-coronavirus/

3. Arli, D. I., \& Lasmono, H. K. (2010). Consumers' perception of corporate social responsibility in a developing country. International Journal of Consumer Studies, 34(1), 46-51. https://doi.org/10.1111/ j.1470-6431.2009.00824.x

4. Auger, P., \& Devinney, T. M. (2007). Do what consumers say matter? The misalignment of the preferences with unconstrained ethical intentions. Journal of Business Ethics, 76(4), 361-383. Retrieved from https://link.springer. com/article/10.1007/s10551-0069287-y

5. Bandura, A. (1986). Social foundations of thought and action. NJ: Prentice Hall.

6. Bhattacharya, C. B., \& Sen, S. (2004). Doing better at doing good: When, Why, And How Consumers Respond To Corporate Social Initiatives. California Management Review, 47(1), 9-24. Retrieved from https:// www.researchgate.net/publication/272553897_Doing_Better_at_ Doing_Good_When_Why_and_ How_Consumers_Respond_To_ Corporate_Social_Initiatives

7. Boccia, F., Rosa, M. M., \& Covino, D. (2019). Consumer behavior and corporate social responsibility: An evaluation by a choice experiment. Corporate Social Responsibility and Environmental Management, 26(1), 97-105. https://doi.org/10.1002/csr.1661

8. Boulstridge, E., \& Carrigan, M. (2000). Do consumers really care about corporate responsibility? Highlighting the attitude-behaviour gap. Journal of
Communication Management, 4, 355-368. https://doi.org/10.1108/ eb023532

9. Brinkmann, J., \& Peattie, K. (2008). Consumer Ethics Research: Reframing the Debate about Consumption for Goods. Electronic Journal of Business Ethics and Organization Studies, 13(1), 22-31. Retrieved from https://biopen.bi.no/bi-xmlui/ handle/11250/93282

10. Carrington, M. J., Neville, B. A., \& Whitwell, G. J. (2010). Why ethical consumers don't walk their talk: towards a framework for understanding the gap between the ethical purchase intentions and actual buying behavior of ethically minded consumers. Journal of Business Ethics, 97(1), 139-158. Retrieved from https:// link.springer.com/article/10.1007/ s10551-010-0501-6

11. Carroll, A. B., \& Shabana, K. M. (2010). The business case for corporate social responsibility: A review of concepts, research and practice. International Journal of Management Reviews, 12(1), 85-105. https://doi.org/10.1111/ j.1468-2370.2009.00275.x

12. Carroll, A. B. (1991). The pyramid of corporate social responsibility: toward the moral management of organizational stakeholders. Business Horizons, 34(4), 39-48 https://doi.org/10.1016/00076813(91)90005-G

13. Carter, N., Bryant-Lukosius, D., DiCenso, A., Blythe, J., \& Neville, A. J. (2014). The use of triangulation in qualitative research. Oncology Nursing Forum, 41(5). Retrieved from https://www.researchgate.net/ publication/265093899_The_Use_ of_Triangulation_in_Qualitative_Research

14. Cherinko, O., \& Balanyuk, A. (2018). Waste Management in Ukraine. Opportunities for Dutch Companies. Final Report for the Embassy of the Kingdom of the Netherlands. Bilfinger Tebodin Ukraine CFI. Kyiv, Ukraine. Retrieved from https://www.rvo. nl/sites/default/files/2019/02/ Waste-management-in-Ukraine. pdf

15. Conroy, P., Porter, K., Nanda, R., Renner, B., \& Narula, A. (2015). Consumer Product Trends. Navigating 2020. Deloitte University Press.

16. Crane, A., Matten, D., Glozer, S., \& Spence, L. (2019). Business Ethics (5th ed.). New York: Oxford University Press.

17. Daszynska-Zygadlo, K., Slonski, T., \& Zawadzki, B. (2016). The Market Value of CSR Performance Across Sectors. Engineering Economics, 27(2), 230-238.

18. De Pelsmaker, P., Driesen, L., \& Rayp, G. (2005). Do consumers care about ethics? Willingness to pay for fair-trade coffee. Journal of Consumer Affairs, 39(2), 363-385. https://doi.org/10.1111/j.17456606.2005.00019.x

19. Dilts, E. (2019, August 19). Top U.S. CEOs say companies should put social responsibility above profit. Reuters. Retrieved from https://www.reuters.com/article/ us-jp-morgan-business-roundtable/top-u-s-ceos-say-companiesshould-put-social-responsibilityabove-profit-idUSKCN1V91EK

20. Du, S., Bhattacharya, C. B., \& Sen, S. (2010). Maximizing Business Returns to Corporate Social Responsibility (CSR): The Role of CSR Communication. International Journal of Management Reviews, 12(1), 8-19. https://doi.org/10.1111/j.14682370.2009.00276.x

21. Elkington, J. (1997). Cannibals with Forks: The Triple Bottom Line of 21st Century Business. Oxford: Capstone.

22. Esmaeilpour, M., \& Barjoei, S. (2016). The impact of Corporate Social Responsibility and Image on Brand Equity. Global Business \& Management Research, 8(3), 55-66.

23. Ethical Consumer. (2019). Markets Report 2018. Retrieved from https://www.ethicalconsumer. 
org/sites/default/files/inline-files/ EC\%20Markets\%20Report\%20 2018\%20FINAL.pdf

24. Farrukh, M. (2016). The effect of corporate social responsibility on consumer buying behaviour: a case of Pakistan. International Journal of Information, Business and Management, 8(1), 242-251. Retrieved from https://search. proquest.com/openview/27c3b18f b53087e3ccedc556869dbf0d/1?pqorigsite $=$ gscholar $\& \mathrm{cbl}=2032142$

25. Fernández, A. M. L., \& Rajagopal. (2013). Influence of corporate social responsibility on consumers' shopping behaviour and determining competitive posture of the firm. Journal of Marketing Analytics, 1(4), 222-233. https:// link.springer.com/article/10.1057/ jma.2013.18

26. Ferreira, A. I., \& Ribeiro, I. (2017) Are you willing to pay the price? The impact of corporate social (ir) responsibility on consumer behaviour towards national and foreign brands. Journal of Consumer Behaviour, 16, 63-71. https://doi.org/10.1002/cb.1603

27. Filosof, J., Hollinshead, G., \& Kurinko, R. (2012). Corporate Social Responsibility in Ukraine: cynical utilitarianism or Aristotelian 'Common Good'? (UH Business School Working Paper). University of Hertfordshire. Retrieved from https://uhra.herts.ac.uk/bitstream/handle/2299/8739/s132. pdf ? sequence $=5$ \&isAllowed $=y$

28. Fishbein, M., \& Ajzen, I. (1975). Belief, attitude and behavior: An introduction to theory and research. MA: Addison-Wesley.

29. Freeman, R. E. (1984). Strategic management: A stakeholder approach. Boston, MA: Pitman.

30. Gladwin, T. N., Kennelly, J. J., \& Krause, T.-S. (1995). Shifting paradigms for sustainable development: Implications for management theory and research. Academy of Management Review, 20(4), 874907. https://doi.org/10.5465/ AMR.1995.9512280024

31. Glanz, K., Rimer, B. K., \& Viswanath, K. (2015). Health
Behaviour. Theory, Research, and Practice (5 ${ }^{\text {th }}$ ed.). San Francisco: Jossey-Bass.

32. Hahn, T., \& Figge, F. (2011). Beyond the Bounded Instrumentality in Current Corporate Sustainability Research: Toward an Inclusive Notion of Profitability. Journal of Business Ethics, 104, 325-345. https://doi.org/10.1007/s10551011-0911-0

33. Hassinger, E. (1959). Stages in the adoption process. Rural Sociology, 24(1), 52.

34. Hoepner, A. G. F., \& Yu, P-S. (2010). Corporate Social Responsibility Across Industries: When Can Who Do Well by Doing Good? https://dx.doi.org/10.2139/ ssrn. 1284703

35. Hsu, K. (2012). The advertising effects of corporate social responsibility on corporate reputation and brand equity: Evidence from the life insurance industry in Taiwan. Journal of Business Ethics, 109(2), 189-201. Retrieved from https:// link.springer.com/article/10.1007/ s10551-011-1118-0

36. Huang, C., Yen, S., Liu, C., \& Huang, P. (2014). The relationship among corporate social responsibility, service quality, corporate image and purchase intention. International Journal of Organizational Innovation, 6(3), 68-84. Retrieved from https:// web.b.ebscohost.com/abstract?direct=true\&profile=ehost\&scope $=$ site $\&$ authtype $=$ crawler $\&$ jrnl $=194$ $31813 \& \mathrm{AN}=94985360 \& \mathrm{~h}=\mathrm{fUBx} 4 \mathrm{z}$ $60 \% 2 \mathrm{bTTX} 2 \mathrm{eO} 4$ drezkIr8TP\%2bC LvynPp1IbhTeSNHKXORtbACm XH1vHGe5osQ8agzcIq75Gw1\%2f 8e0OUHKl\%2fg\%3d\%3d\&crl=c\&r esultNs=AdminWebAuth\&resultL ocal=ErrCrlNotAuth\&crlhashurl= login.aspx $\% 3$ fdirect $\% 3$ dtrue $\% 26 p$ rofile $\% 3$ dehost $\% 26$ scope $\% 3$ dsite $\%$ 26authtype\%3dcrawler\%26jrnl\%3 d19431813\%26AN\%3d94985360

37. ING. (2018). From Sustainability to Business Value. Finance as catalyst. Retrieved from https://www. ingwb.com/media/2266556/ingsustainability-study-2018.pdf

38. Jackson, T. E. (2006). The Earthscan Reader in Sustainable Consumption. London.
39. Jones, P., Comfort, D., Hillier, D., $\&$ Eastwood, I. (2005). Corporate social responsibility: A case study of the UK's leading food retailers. British Food Journal, 107(6), 423-435. https://doi. org/10.1108/00070700510602192

40. Kannaiah, D., \& Jayakumar, A. (2018). Impact of Corporate Social Responsibility (CSR) Practices on Consumer Behaviour (with Reference to FMCGs in Tamil Nadu). International Journal of Business and Management, 13(3), 28-41. Retrieved from http://www. ccsenet.org/journal/index.php/ ijbm/article/view/72540

41. Karaosman, H., Morales-Alonso, G., \& Grijalvo, M. (2015). Consumers' responses to CSR in a cross-cultural setting. Cogent Business \& Management, 2, 1-18. https://doi.org/10.1080/23311975. 2015.1052916

42. Karhova, V. (2018). Challenges and Problems of Solid Waste in Ukraine. The Ukrainian Journal of Business and Law, 11. Retrieved from http://www.ujbl.com/article. php?id=1176

43. Kim, S., \& Ferguson, M. T. (2014). Public Expectations of CSR Communication: What and How to Communicate CSR. Public Relations Journal, 8(3), 1-22. Retrieved from https:// www.bellisario.psu.edu/assets/ uploads/2014KIMFERGUSON. pdf

44. Kim, S., \& Ferguson, M. T. (2018). Dimensions of effective CSR communication based on public expectations. Journal of Marketing Communications, 24(6), 549-567. Retrieved from https:// www.researchgate.net/publication/290221170_Dimensions_of_ effective_CSR_communication based_on_public_expectations

45. Kotler, P., \& Lee, N. (2005). Corporate Social Responsibility: Doing the Most Good for Your Company and Your Cause. Hoboken, New Jersey: John Wiley \& Sons.

46. Kronthal-Sacco, R., \& Whelan, T. (2019). Sustainable Share Index: Research on IRI Purchasing Dato (2013-2018). NYU Stern Center 
for Sustainable Business. Retrieved from https://www.stern. nyu.edu/sites/default/files/assets/ documents/NYUSternCSB_SustainableShareIndex_2019.pdf

47. Kurinko, R. (2016, April 5). National CSR strategy in Ukraine: actual state and perspectives. Gurt 25 Rokiv - Group 25 Years. (In Ukrainian). Retrieved from https://www.gurt.org.ua/articles/31876/

48. Kurucz, E., Colbert, B., \& Wheeler, D. (2008). The Business Case for Corporate Social Responsibility. In A. Crane, A. McWilliams, D. Matten, J. Mood, \& D. Seigel (Eds.), The Oxford Handbook of Corporate Social Responsibility (pp. 83-112). Oxford: Oxford University Press.

49. Kuryshko, D. (2018). 500 pyramids of Cheops: the amount of garbage in Ukraine. BBC News. Ukraine. (In Russian). Retrieved from https://www.bbc.com/ukrainian/features-russian-43417368

50. Lee, C., Chang, W., \& Lee, H. (2017). An investigation of the effects of corporate social responsibility on corporate reputation and customer loyalty - evidence from the Taiwan non-life insurance industry. Social Responsibility Journal, 13(2), 355-369. Retrieved from https://www.researchgate. net/publication/317222059_An_ investigation_of_the_effects_of_ corporate_social_responsibility_on_corporate_reputation_and_ customer_loyalty_-_Evidence_ from_the_Taiwan_non-life_insurance_industry

51. McCracken, G. (1988). The long interview. Newbury Park, CA: Sage.

52. Miles, M. B., Huberman, A. M., \& Saldaña, J. (2014). Qualitative Data Analysis: A Methods Sourcebook. Sage Publications.

53. Oberseder, M., Schlegelmilch, B. B., \& Gruber, V. (2011). Why don't consumers care about CSR?: A qualitative study exploring the role of CSR in consumption decisions. Journal of Business Ethics, 104(4), 449-460. Retrieved from https://link.springer.com/article/10.1007/s10551-011-0925-7
54. Oberseder, M., Schlegelmilch, B. B., \& Murphy, P. E. (2013). CSR practices and consumer perceptions. Journal of Business Research, 66, 1839-1851. https://doi. org/10.1016/j.jbusres.2013.02.005

55. Palinkas, L. A., Horwitz, S. M., Green, C. A., Wisdom, J. P., Duan, N, \& Hoagwood, K. (2015). Purposeful sampling for qualitative data collection and analysis in mixed method implementation research. Adm Policy Ment Health, 42(5), 533544. Retrieved from https://www. ncbi.nlm.nih.gov/pmc/articles/ PMC4012002/

56. Panapanaan, V. M., Linnanen, L., Karvonen, M. M., \& Phan, V. T. (2003). Roadmapping corporate social responsibility in Finnish companies. Journal of Business Ethics, 44(2/3), 133-148. Retrieved from https://link.springer.com/article/10.1023/A:1023391530903

57. Park, J., Lee, H., \& Kim, C. (2014). Corporate social responsibilities, consumer trust and corporate reputation: South Korean consumers' perspectives. Journal of Business Research, 67(3), 295302. https://doi.org/10.1016/j. jbusres.2013.05.016

58. Peloza, J., \& Shang, J. (2011). How can corporate social responsibility activities create value for stakeholders? A systematic review. Journal of the Academy of Marketing Science, 39(1), 117135. Retrieved from https://link. springer.com/article/10.1007/ s11747-010-0213-6

59. Petty, R. E., \& Cacioppo, J. T. (1986). The Elaboration Likelihood Model of Persuasion. Advances in Experimental Social Psychology, 19, 123-205. https://doi.org/10.1016/S00652601(08)60214-2

60. Pomering, A., \& Dolnicar, S. (2009). Assessing the Prerequisite of Successful CSR implementation: Are Consumers Aware of CSR initiatives? Journal of Business Ethics, 85, 285-301. Retrieved from https://link.springer.com/article/10.1007/s10551-008-9729-9

61. Raza Naqvi., S. M. M. (2013). Impact of Corporate Social responsibility on Brand image in Different FMCGs of Pakistan. Interdisciplinary Journal of Contemporary Research in Business, 5(1), 79-93. Retrieved from https://journal-archieves32.webs. com/79-93.pdf

62. Rockström, J., Steffen, W., Noone, K., Persson, Å., Chapin, III, F.S., Lambin, E., Lenton, T.M., Scheffer, M., Folke, C., Schellnhuber, H., Nykvist, B., De Wit, C.A., Hughes, T., van der Leeuw, S., Rodhe, H. Sörlin, S., Snyder, P.K., Costanza, R., Svedin, U., Falkenmark, M., Karlberg, L., Corell, R.W., Fabry, V.J., Hansen, J., Walker, B., Liverman, D., Richardson, K., Crutzen, P., \& Foley, J. (2009). Planetary boundaries: exploring the safe operating space for humanity. Ecology and Society, 14(2), 32. Retrieved from http:// www.ecologyandsociety.org/vol14/ iss $2 / \operatorname{art} 32 /$

63. Sachs, J., Schmidt-Traub, G., Kroll, C., Lafortune, G., \& Fuller, G. (2019). Sustainable Development Report 2019. Bertelsmann Stiftung and Sustainable Development Solutions Network (SDSN).

64. Sachs, J., Schmidt-Traub, G., Kroll, C., Lafortune, G., Fuller, G., \& Woelm, F. (2020). The Sustainable Development Goals and COVID-19. Sustainable Development Report 2020. Cambridge: Cambridge University Press.

65. Saldana, J. (2015). The coding manual for qualitative researchers. Sage.

66. Saunders, M., Lewis, P., \& Thornhill, A. (2007). Research methods for business students (4th ed.). Essex, England: Pearson Education.

67. Schmeltz, L. (2012). Consumeroriented CSR communication: focusing on ability or morality? Corporate Communications: An International Journal, 17(1), 29-49. https://doi. org/10.1108/13563281211196344

68. Schramm-Klein, H., Zentes, J., Steinmann, S., Swoboda, B., \& Morschett, D. (2016). Retailer corporate social responsibility is relevant to consumer behavior. Business and Society, 
55(4), 550-575. https://doi.org/10.1177\%2F0007650313501844

69. Sen, S., \& Bhattacharya, C. B. (2001). Does doing good always lead to doing better? Consumer reactions to corporate social responsibility. Journal of Marketing Research, 38(2), 225243. https://doi.org/10.1509\%2Fjm kr.38.2.225.18838

70. Sen, S., Bhattacharya, C. B., \& Korschun, D. (2006). The role of corporate social responsibility in strengthening multiple stakeholder relationships: A field experiment. Journal of the Academy of Marketing Science, 34(2), 158-166. Retrieved from https://link.springer.com/article/10.1177/0092070305284978

71. Spiller, R. (2000). Ethical business and investment: A model for business and society. Journal of Business Ethics, 27(1/2), 149160. Retrieved from https://link. springer.com/article/10.1023 /A:1006445915026

72. Staudt, S., Shao, C. Y., Dubinsky, A. J., \& Wilson, P. H. (2014). Corporate Social Responsibility, Perceived Customer Value, and Customer-Based Brand Equity: A Cross-National Comparison. Journal of Strategic Innovation \& Sustainability, 10(1), 65-87. Retrieved from http://na-businesspress.homestead.com/JSIS/ADubinskyWeb10-1.pdf

73. Steurer, R., \& Konrad, A. (2009). Business-society relations in Central-Eastern and Western Europe: How those who lead in sustainability reporting bridge the gap in corporate (social) responsibility. Scandinavian Journal of Management, 25, 23-36.

74. The Verkhovna Rada of Ukraine. (2013, June 25). Legislation of Ukraine. Presidential decree regarding the Action Plan for the implementation in 2013 of the Strategy of the state policy to promote the development of civil society in Ukraine. (In Ukrainian) Retrieved from https://zakon.rada.gov.ua/laws/ show/342/2013?lang=en

75. The World Bank. (2018). International Comparison Program data- base. GDP per capita, PPP (current international \$). Retrieved from https://data.worldbank.org/indicator/NY.GDP.PCAP.PP.CD?most recent_value_desc $=$ true

76. Thøgersen, J., \& Zhou, Y. (2012). Chinese consumers' adoption of a 'green' innovation - The case of organic food. Journal of Marketing Management, 28(3-4), 313-333. https://doi.org/10.1080/026725 7X.2012.658834

77. Tian, Z., Wang, R., \& Yang, W. (2011). Consumer responses to corporate social responsibility (CSR) in China. Journal of Business Ethics, 101(2), 197-212. Retrieved from https://link.springer. com/article/10.1007/s10551-010 0716-6

78. Torres, A., Bijmolt, T. H. A., \& Tribó, J. A. (2012). Generating global brand equity through corporate social responsibility to key stakeholders. International Journal of Research in Marketing, 29, 13-24. https://doi.org/10.1016/j.ijresmar.2011.10.002

79. Vázquez-Burguete, J. L., SahelicesPinto, C., \& Lanero-Carrizo, A. (2017). Corporate social responsibility and consumer behaviour in the cosmetics sector: A study in the Spanish context. International Review on Public and Non - Profit Marketing, 14(3), 375-390. Retrieved from https://www.researchgate.net/ publication/315629981_Corporate_social_responsibility_and_ consumer_behavior_in_the_cosmetics_sector_a_study_in_the_ Spanish_context

80. Vorobey, V. (2005). In Search of National Identity. In A. Habisch, M. Wegner, R. Schmidpeter, \& J. Jonker (Eds.), Corporate Social Responsibility Across Europe. New York: Springer-Verlang New-York Inc.

81. Wang, D. H., Chen, P., Yu, T. H., \& Hsiao, C. (2015). The effects of corporate social responsibility on brand equity and firm performance. Journal of Business Research, 68(11) 2232-2236. Retrieved from https://www.researchgate.net/ publication/281190108_The_ef- fects_of_corporate_social_responsibility_on_brand_equity_and_ firm_performance

82. Wang, L., \& Juslin, H. (2009). The impact of Chinese culture on corporate social responsibility: The harmony approach. Journal of Business Ethics, 88, 433-451. Retrieved from https://link.springer. com/article/10.1007/s10551-0090306-7

83. Worthington, I. (2013). Greening Business: Research, Theory, \& Practice. Oxford: Oxford University Press.

84. Yin, R. K. (2014). Case study research: Design and methods (5th ed.). Thousand Oaks, CA: Sage. 


\section{APPENDIX A}

Table A1. Overview of experts participated in the interviews

\begin{tabular}{|c|c|c|c|}
\hline Participant & Company & CSR adoption level & Position \\
\hline Expert 1 & $\begin{array}{l}\text { Large FMCG distributor with own } \\
\text { production (UA-based) }\end{array}$ & No CSR strategy, fragmented CSR activities & Private label director \\
\hline Expert 2 & P\&G Ukraine & Well-developed CSR strategy & $\begin{array}{l}\text { Corporate communication and } \\
\text { CSR }\end{array}$ \\
\hline Expert 3 & $\begin{array}{l}\text { Large producer of bottled water } \\
\text { (UA-based) }\end{array}$ & $\begin{array}{c}\text { CSR strategy is being actively developed; } \\
\text { several CSR projects were launched over the } \\
\text { last few years }\end{array}$ & $\begin{array}{l}\text { Communication manager } \\
\text { (involved in CSR projects) }\end{array}$ \\
\hline Expert 4 & $\begin{array}{c}\text { Second largest retail chain in } \\
\text { Ukraine (UA-based) }\end{array}$ & $\begin{array}{c}\text { CSR strategy is being actively developed; } \\
\text { several CSR projects were launched over the } \\
\text { last few years }\end{array}$ & Senior project manager \\
\hline Expert 5 & $\begin{array}{c}\text { Consulting company "Center of } \\
\text { CSR development" }\end{array}$ & Well-developed CSR strategy & Founder and CEO \\
\hline
\end{tabular}

\section{APPENDIX B}

Table B1. Overview of consumers participated in the interviews

\begin{tabular}{l|c:c|c|c}
\hline Participant & Age & Gender & Income & $\begin{array}{c}\text { Level of responsible consumption } \\
\text { adoption }\end{array}$ \\
\hline Consumer 1 & 31 & Male & Higher than average & Medium/high \\
\hline Consumer 2 & 32 & Hemale & Higher than average & Low \\
\hline Consumer 3 & 35 & Female & Higher than average & Medium/high \\
\hdashline Consumer 4 & 30 & Hemale & Higher than average & Medium \\
\hdashline Consumer 5 & 28 & Hemale & Higher than average & High \\
\hline
\end{tabular}

